\title{
ACHIEVEMENTS OF ENGINEER, ENTREPRENEUR AND TEACHER JĀNIS BAUMANIS (1878-1945)
}

\section{LĀSMA GAITNIECE* , ALĪDA ZIGMUNDE \\ Riga Technical University}

\begin{abstract}
Summary. The article is devoted to engineer, teacher and one of mayors of Liepāja City Municipality - Jānis Baumanis - who obtained university education not only at Riga Polytechnic Institute (RPI), but also at the University of Electricity (Ecole supérieure d'electricité) in Paris, France. The biography of J. Baumanis shows that he has been purposeful, feared no challenge and has repeatedly proved himself as entrepreneur establishing and successfully managing companies. These qualities also describe J. Baumanis as the Mayor of Liepāja City Municipality, but the desire to take initiative in implementing various, brave at that time, ideas were interfering, thus he held the position less than a year. After resigning, he left Liepāja city for Riga, where he worked for a company and turned to pedagogical work. The aim of the article is to summarize the life of J. Baumanis and to discover his achievements in various fields of activity.
\end{abstract}

Keywords: Jānis Baumanis, Riga Polytechnic Institute, Liepāja City Municipality, company «Rūpnieks» («Manufacturer»).

\section{Introduction}

Jānis Baumanis was a very well-educated and successful business person who had his own businesses not only in Latvia but also in France and Russia. He was also an energetic public worker.

Although J. Baumanis had worked in various fields, held the position of the Mayor of Liepaja City Municipality, been the founder and manager of company «Rūpnieks» («Manufacturer»), information about his life and economic activities is very scrimpy. There are only some articles about the activities of $J$. Baumanis in the publications of regional press (newspaper «Kurzemes Vārds» («Courland's Voice»), magazine «Liepājas Véstules» («Letters of Liepāja City») are available and his name is rarely

* Corresponding author.

E-mail: lasma.gaitniece@rtu.lv 
mentioned there, without any mention about his activities and contribution to Liepāja city and Latvia on the whole.

When studying the activities of J. Baumanis and identifying publications about him, it was concluded that his activities in the position of Mayor of Liepāja city did not seem to be of interest to the researchers of the history of Liepaja city, in comparison to the number of available materials and research on his predecessors and successors.

This article is the first extensive study on the life and work of J. Baumanis. Materials from the Latvian National Archives, Latvian State Historical Archive as well as materials from the National Library of Latvia have been used when writing this article.

\section{Biography of J. Baumanis}

J. Baumanis was born on 13 August 1878 in Liepāja city in the family of Trine Baumane and Jēkabs Baumanis. They were a Lutheran family. In 1899, he graduated from the Liepāja City Real School and on 1 September of the same year he enrolled in the Department of Mechanics of RPI and studied there for five years. He graduated in June 1904 with a degree in engineering technology [1]. After graduating from the university, in the same year, J. Baumanis married Milija Kalvina (1879-1936). J. Baumanis' family had a son Ansis Baumanis (1905-?), who wanted to join the Faculty of Architecture of the University of Latvia in 1925. Unfortunately, he did not pass the competition, therefore he began studies in the Faculty of Mechanics, but after two semesters, he left the studies [2].

In the 1920s, the engineer lived at Matisa iela in Riga and in the 1930s, in Salas parish (at present - Priedaine - residential area and neighborhood of Jūrmala city). In 1936, he suffered a serious loss - his wife died. J. Baumanis married for a second time and his spouse was German. When World War II began, German people were leaving Latvia and J. Baumanis also left Latvia with his second wife.

On 30 November 1939, J. Baumanis wrote to the Minister of the Interior of Latvia asking to allow him to renounce Latvian citizenship [3]. He noted that he was German, although he was Latvian. He was not the only one who acted like that. Engineer J. Baumanis settled in Poznań, Poland. Ethnic Germans and Baltic Germans emigrating from Eastern Europe and people of other nationalities were deployed in Poznań and its surroundings.

The life of an engineer ended in autumn 1945 in Germany. 


\section{Engineer and Entrepreneur J. Baumanis}

With a Bachelor's degree from RPI J. Baumanis went to England, where he practiced in various steam turbine mechanical plants, but already in 1905, he moved to St. Petersburg. J. Baumanis had worked at «Wossidlo \& Co», «Worthington Pump Co., Ltd» and in the Baltic Shipbuilding and Mechanical Plant. At that time, steam turbines were built in these plants and specialists were needed in this area. J. Baumanis was chosen as a specialist of this area and was sent to learn more about steam turbines abroad. At first, the engineer visited various firms in England («Parsons \& Co. Ltd. Wallsend on Tyne John Brown» in Glasgow, etc.), representation of «Brown, Boveri \& Co» in Mannheim (Germany), Baden (Switzerland) and Lille (France). In the 1920s, J. Baumanis wrote in his autobiography: "After a one and a half year mission, I worked in St. Petersburg until 1908, when cholera emerged, then I left the city and travelled to Italy - to Riviera di Levante and then to Paris» [4].

J. Baumanis lived in the capital of France - Paris, for four years, until 1912. At the time he studied at the Ecole supérieure d'electricité (University of Electricity; 1908-1911). It should be noted that the diploma of this institution was not recognized as university diploma by the Council Meeting (on 5 January 1926) of the Faculty of Mechanics of the University of Latvia [5]. From 1910, in parallel with his studies, he was the owner and employee of the company «Bauman et Peters». But in 1912, J. Baumanis went to the city of Tsarist Russia - Moscow, where he worked as an engineer at the company «International Harvester Corparation Liubertzi Works». In the autobiography of J. Baumanis, published in 1928 in the edition of the Latvian Student Corporation "Talavija», he wrote about his further work in Moscow. The article tells that in 1913, J. Baumanis established his own company under the name «Inženieru birojs Baumans \& Redlichs» («Engineers' Office Baumans \& Redlichs»), opened in 1913 at 46 Mjasnitckaja, Moscow [6]. It is believed that there is a mistake in the publication because at the end of the 20th century in the civil servant's questionnaire J. Baumanis stated that he had owned a company in Moscow from 1917 to 1919. Prior to that, from 1915 to 1917, he took part in reorganization of a factory [7].

J. Baumanis specialized in the construction and installation of factories and gave various presentations. At the Riga Polytechnicans' Society in Moscow he gave presentations on a new method of smelting cast iron [8] and dyeing by immersing small objects in paint [9]. Both presentations were published. In addition, the presentation at the Moscow District Technology Society on intensification of work in metal cutting was also published [10]. In his autobiography, engineer J. Baumanis stated that he was the author of another brochure, «Metālu apstrādāšana un 
iekārta pēc Taylora sistēmas» («Metal Processing and Equipment using Taylor System»), the year of issue of which is unknown [11]. All editions were in Russian and the author's name was russified into Ivan. J. Baumanis with his family lived in Russia until 1918.

On his return to Latvia, J. Baumanis founded company «Rūpnieks» («Manufacturer») in Liepāja city in 1920, where distillation of tar and turpentine was carried out. He was Director of the company. It was located at 21 Graudu iela in Liepajja city [12]. Already in the summer of 1921, «Rūpnieks» participated in the first International Exhibition of Agriculture and Industry in Riga, displaying its produce of dry distillation of wood [13]. The produce was exhibited in the pavilion of the Ministry of Agriculture of the Republic of Latvia along with other apparatus made by engineer - graduate of the Department of Chemistry (1916) of RPI Arvìds Kalniņš (1894-1981), Associate Professor of the Department of Forestry of Latvia University of Agriculture.

In the autumn of 1922, J. Baumanis left Liepāja city. He moved to Riga, where together with his brother Augusts Baumanis (1883-1966) turned to business again, establishing a company that installed central heating and sewerage and carried out engineering works related to their maintenance. One of the projects developed by J. Baumanis was mechanization of Kemeri Sulfur Springs [14]. Both brothers had also established a woodworking company «Eksports», which operated in the middle of 1920s.

\section{J. Baumanis - Mayor of Liepāja City (1921-1922)}

After the Russian Revolution of 1917, engineer J. Baumanis did not want to stay in the Bolshevik-controlled country and shortly before the proclamation of the Republic of Latvia, in October 1918, returned to Liepāja city. When the Bolsheviks approached Liepāja city, J. Baumanis and several members of the Latvian Provisional Government left for Szczecin in Germany (at present - in Poland), where he lived until 1920. After returning to Liepajja city, the engineer started his business.

The passport of J. Baumanis (No. 8640), which was issued by the Prefect of Liepaja city on 24 April 1920, proves that during this period his permanent place of residence was indeed Liepāja city. Also in 1922, J. Baumanis lived in Liepāja city, as evidenced by the stamp on participation in the elections of Saeima in the Kurzeme (Courland) Electoral District. The passport was cancelled on 26 March 1928, when J. Baumanis left the city again [15]. 


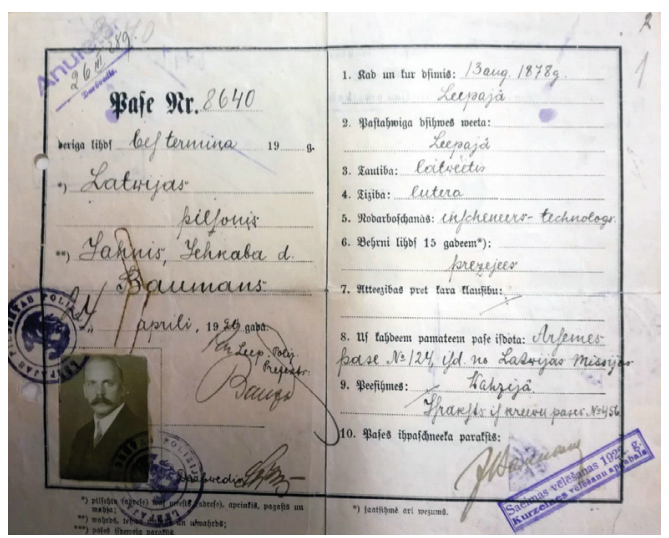

Figure 1. The passport of a citizen of the Republic of Latvia Jānis Baumanis (1920) [15].

After proclamation of the Republic of Latvia on 18 November 1918, inhabitants of Liepāja city experienced frequent changes of Government. Several well-educated, prospective and respectable men had been elected Mayors of Liepāja city, but they left the position already after one year. This situation was characteristic in the early 1920s when the effects of World War I were still felt. During this time, the city had economic decline and long lasting shortage of funds in the city treasury caused by increasing expenses and low tax revenues.

In the Liepāja City Council elections of 16 January 1921 the so-called civilian-wing dominated. Jèkabs Cincelis (1881-1951) was elected Mayor of Liepāja city. The economic situation of the city was bad, which caused disagreements in the city administration and J. Cincelis resigned. On 29 August of the same year, J. Baumanis was elected Mayor of Liepāja city, he resigned already on 27 February 1922. On 16 March, Evalds Rimbenieks [16] (1888-1943), member of the Liepāja City Council, was elected Mayor of Liepāja city.

It has to be noted that in one of his autobiographies J. Baumanis wrongly stated that he was elected Mayor of Liepajja city in September 1922 [17]. However, the Liepaja Museum confirms that J. Baumanis was the Mayor of Liepāja city from 29 August 1921 until 27 February 1922 and on 16 March 1922, E. Rimbenieks was elected [18]. This was also confirmed by the announcement in the official newspaper of the Government of the Republic of Latvia «Valdības Vēstnesis» («The Newspaper of the Government») on 31 August 1921. J. Baumanis was elected Mayor of Liepaja city with 27 votes in favour and 21 vote against him, while $\bar{E}$. Rimbenieks was elected his Vice-Chairman with 26 votes in favour and 22 votes against him [19].

Historians Ula Gintners and Jānis Gintners point out that from 29 August 1921 to 27 February 1922, the time when J. Baumanis was the Mayor of Liepajja city, «he was economically minded and showed a lot of 
initiative. On 18 February 1922, in the large hall of the City Council, a three-and-a-half-hour meeting was held at which Baumanis outlined the activities necessary for the development of Liepajja city: the foundation of the City Bank and of the Liepāja City Fire Insurance Society, the transformation of the Gas and Electricity Factory into a Joint Stock Company and the establishment of the Departments of Liepāja City Trade and Industry. Among the 25 listeners were representatives from trade and industry, foreign consuls, members of the City Council and others. The ideas presented by J. Baumanis were approved with minor remarks by everyone present» [20].

On 23 February 1922, a meeting of the Liepāja City Council took place when «during the discussions on budgetary matters distrust in the leaders of the city was expressed. After voting 30 votes were in favour and 22 - against. Baumanis resigned. Maybe he had lived too fast. Intentions were ahead of time» [21].

The work of engineer and entrepreneur J. Baumanis when being Mayor of Liepāja city was not easy, because after World War I, there was extreme poverty and the city treasury was almost empty. Historian J. Gintners reveals that during that time several major changes took place, which in the coming years contributed to the economic prosperity of Liepaja city. In 1920, the Latvian Government authorized the opening of the Free Port in Liepajja city - a certain part of the territory of the city port where foreign goods can be imported and carried out without taxes and formalities. The storage of goods in the Free Port territory was also exempt from taxes. The Latvian Government allocated 130000 lats for the establishment of the Free Port. At the beginning of the 1920s, the city administration discussed the need for building a new railway line. The aim was to connect Courland and Semigalia agricultural districts with the transit of Liepāja City Port, therefore on 19 July 1922, the Constitutional Assembly of Latvia decided to entrust the Government to prepare the construction of a new railway line to Liepajja city. New sections of the new railway line were opened in 1927 and 1928. The whole Liepāja-Glūda (Jelgava city) line was completed in autumn 1929.

Along with the concern about the establishment of the Free Port and the new railway network in the beginning of the 20th century, the renovation of industry in Liepajja city was also not forgotten. Karaosta (Military Port) workshops, which were the largest industrial enterprises in Liepajja city in the early years of the Republic of Latvia and later, at the beginning of 1922, were transformed into a state-owned company - machine building and a ship repair factory. After reorganization, the company rapidly expanded its operation due to big orders from the military sector and orders placed by the Ministry of Transport of the Republic of Latvia. The Ministry placed orders with the Military Port of 
Liepajja city for the production of goods and passenger wagons, as well as tram wagons for the capital's needs, the construction of the Riga Floating Bridge and the metal constructions of the Kalpaka Bridge. In 1920, major changes took place in the second largest enterprise of the time - the Liepajja Wire Factory, which was known at the end of the 20th century and the beginning of the 21st century as Joint Stock Company «Liepājas metalurgs». In the early 1920s, the company re-established itself as a JointStock Company for the North-evening Mechanical and Building Factory. In 1923, the foundry was expanded, a kiln for cast iron smelter and the Simensens' Oven that weighed five tonnes were built [22].

\section{Pedagogical Work of J. Baumanis in Riga}

From 1927, the experienced engineer and entrepreneur turned to pedagogy. He started working in Riga State Technical School as a teacher of industrial organization and drawing. The students of the Technical School practiced drawing techniques, learned about the rules of technical drawings and practiced to make drawings of machine parts [23]. For the job of teaching students, J. Baumanis had both suitable education and experience in drawing various projects. He worked in the Department of Mechanics [24]. Many RPI graduates worked in the Technical School, including the members of Student Corporation «Talavija». J. Baumanis was one of the founders of «Talavija» and knew Ansis Grinnbergs, Director of Technical School (1880-1930), as well as teachers (also members of corporation) Jānis Lukstiñš (1883-1953), Kārlis Timušks (1877-1958), Ādolfs Vickopfs (1878-1967) and others [25].

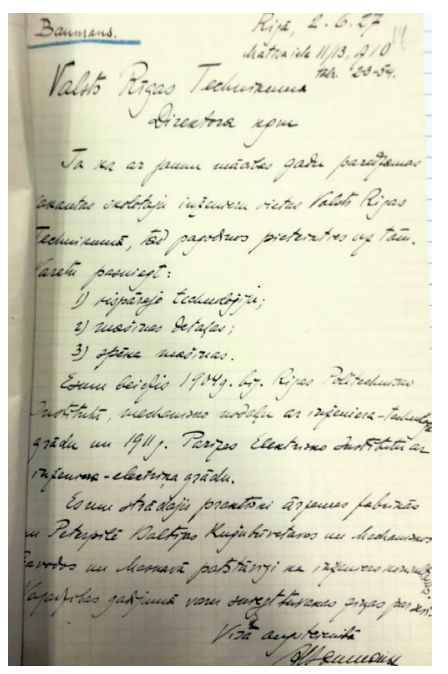

Figure 2. Application of J. Baumanis to the Director of Riga State Technical School for the position of a teacher, on 2 June 1927 [26]. 
J. Baumanis also worked as a teacher in Riga State Craft School and Technical School (1927-1939). J. Baumanis stopped working as a teacher on 1 December 1939.

Figure 3. Jānis Baumanis (in the 1930s) [27].

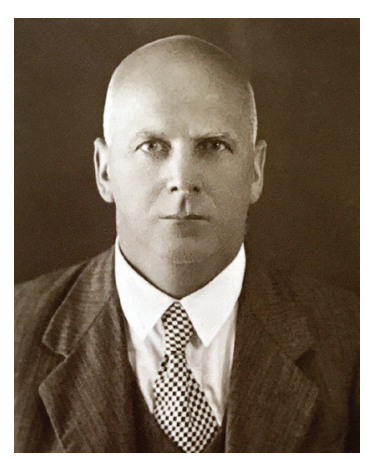

On 3 February 1943, J. Baumanis wrote an application to the Department of Vocational Schools of the Latvian Ministry of Education asking to confirm the length of his service as a teacher [28]. Apparently he was collecting documents for retirement. He did not continue teaching in Germany.

Figure 4. The excerpt from the request of $J$. Baumanis to the Department of Vocational Schools of the Latvian Ministry of Education to certify the length of his service as a teacher (1943) [28].

\section{Conclusions}

The life of engineer, entrepreneur and teacher J. Baumanis is connected with both Tsarist Russia and Western Europe, where he went after his studies in the 1930s. The companies founded by him were operating for a short time because of the changes of political situation in Russia changed and probable financial problems in Latvia. The years spent in Liepāja city were important in J. Baumanis' life. In 1920, he founded company «Rūpnieks» and at the end of August 1921 became the Mayor of Liepajja city. Although he held this position only half a year, the history of Liepāja city is unthinkable without J. Baumanis. It is important that it will be possible to add a photo of J. Baumanis in the Gallery of Liepāja City Mayors. Before this research the photo had not been available.

The pedagogical work of J. Baumanis has also been significant and resulted in educated professional technical staff. He was a public figure
Achievements

of Engineer,

Entrepreneur and

Teacher

Jānis Baumanis

(1878-1945) 
and engaged in the work of the association of RPI graduates or Riga «polytechnicans» in Moscow. In 1900, J. Baumanis and later well-known Latvian engineers and public figures Kārlis Timušks, Ādolfs Vickopfs, as well as Hugo Celmiñš (1877-1941), August Malvess (1878-1951), Pauls Sakss (1878-1966) and others founded the second Latvian Student Corporation «Talavija» [29].

\section{CONFLICT OF INTEREST}

The authors of the scientific article acknowledge a conflict of interest related to the joint professional work of the authors and members of the Editorial Board. The inclusion of this article in the issue was decided by those members of the Editorial Board who are not the authors of this article.

\section{LIST OF SOURCES AND LITERATURE}

[1] RPI studentu reǵistrs. Latvijas Nacionāla arhīva Latvijas Valsts vēstures arhīvs (turpmāk - LNA LVVA) 7175. f., 1. apr., 1906. l., 28. lp.

[2] Jāṇa Baumaṇa lūgums izsniegt viṇa dēlam Ansim apliecinājumu par studijām Latvijas Universitātē 1925./1926. mācību gadā. LNA LVVA 7427. f., 1. apr., 9822. 1., 11. lp.

[3] J. Baumaṇa lūgums Latvijas iekšlietu ministram atḷaut atteikties no Latvijas pavalstniecības, 1939. g. LNA LVVA 3721. f., 4. apr., 126. 1., 178. lp.

[4] Baumanis, J. Talavija, 1900-1925. Rīga: Valters un Rapa, 1928, 35. lpp.

[5] Latvijas Universitātes Mehānikas fakultātes dekāna K. Tormaṇa vēstule Izglīīibas ministrijai 1931. gada janvārī. LNA LVVA 1632. f., 1. apr., 1542. 1., 17. lp.

[6] Baumanis, J. Talavija, 1900-1925. Rīga: Valters un Rapa, 1928, 35. lpp.

[7] Ierēdṇa Jāṇa Baumaṇa ankete. LNA LVVA 6912. f., 1. apr., 56. l., 12. lp.

[8] Bauman, I. J. Novij sposob plavki chuguna v vagrankah. Moskva: Zemlja, 1915, 16 str.

[9] Bauman, I. J. Sposob okrashivanija mashinnyh chastej okunanijem. Moskva: Zemlja, 1915, 16 str.

[10] Bauman, I. J. Iz praktiki po intensifikacii truda pri rezanii metallov. Moskva: Zemlja, 1915, 23 str.

[11] Baumanis, J. Talavija, 1900-1925. Rīga: Valters un Rapa, 1928, 35. Ipp.

[12] Latvijas tirdzniecības un rūpniecības adresu grāmata 1922./1923. gadā. 2. izd. [Rīga]: J. A. Kukurs, [1922], 307. lpp.

[13] Stūls, A. Rīgas izstāde. Ekonomists, 1921, Nr. 17, 1921. gada 1. septembris, 635. lpp.

[14] Baumanis Jānis. Rīgas Politechnikums 1862.-1919.g.: Album academicum (1912.-1919. g.). Rīga: Latvijas universitātes studentu [padomes] grāmatnīca, 1938, 76. lpp.

[15] Jān,a Baumaṇa Latvijas Republikas pilsoṇa pase, 1920. gads. LVVA. 2996. f., 2. apr., 9356. 1., 1. lp. 
[16] Deksnis, E. Laba un skaidra apziṇa, ko nekad nedrīkst pazaudēt. Kurzemes Vārds, 2005, 14. jūnijs, 6. lpp.

[17] Baumanis, J. Talavija, 1900-1925. Rīga: Valters un Rapa, 1928, 35. lpp.

[18] Liepājas Muzejs [tiešsaiste]. http://ej.uz/Liepajas_vaditaji17-21gs [skatīts: 2018. gada 26. septembrī].

[19] Telegramas. Valdības Vēstnesis, 1921, Nr. 195, 1921. gada 31. augustā, 3. lpp.

[20] Gintners, J., Gintnere, U. Pašu valdība jeb pašvaldība. Liepājas Vēstules, 2017, Nr. 3 (31), 42. lpp.

[21] Liepājas Muzejs [tiešsaiste]. http://ej.uz/Liepajas_vaditaji17-21gs [skatīts: 2018. gada 26. septembrī].

[22] Gintners, J. 20. gadsimts laikmetu griežos. Kurzemes Vārds, 2000, 13.janvāris, 6.-7. lpp.

[23] Valsts tehnikums Rīgā: desmit gadu darbības pārskats, 1920.-1930. Rīga: Valsts Tehnikums, 1930, 56., 77. lpp.

[24] Grosvalds, I., Bombiza, I. Tehniska izglītība Latvijā un Rīgas Valsts tehnikums. RTU zinātniskie raksti. Humanitārās un sociālās zinātnes. Nr.19, 2012, 34. lpp.

[25] Album Academicum des Polytechnikums zu Riga, 1862-1912. Riga: Jonck \& Poliewsky, 1912, S. 468, 501, 517.

[26] J. Baumaña iesniegums Rīgas Valsts tehnikuma direktoram pieñemšanai darbā par skolotāju. LNA LVVA 6912. f., 1. apr., 56. l., 14. lp.

[27] Jāṇa Baumaṇa Latvijas Republikas ārzemju pase. LNA LVVA 3234. f., 33. apr., 86928. 1., 3. Ipp.

[28] J. Baumaṇa lūgums Latvijas izglītības ministrijas Arodskolu nodal̦ai apliecināt viņa darba stāžu, 1939. gads. LNA LVVA 1632. f., 1. apr., 1542. l., 5.lp.

[29] Talavija, 1900-1925. Rīga: Valters un Rapa, 1928, XIV lpp.

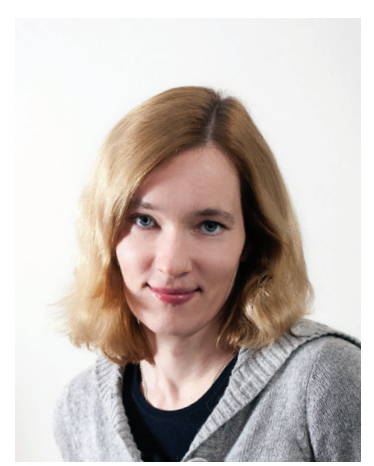
University of Mainz (Germany) and a teacher of Latvian as a second language in Riga 1st Medical College. Address: 1 Kronvalda bulvāris, Riga, LV-1010, Latvia

Phone: +37129844524

E-mail: lasma.gaitniece@rtu.lv
LĀSMA GAITNIECE, $M g$. philol., graduated from Liepaja Pedagogical Academy in 2005. She received a professional degree in Public Relations from Liepaja University in 2012. She is currently a Latvian language instructor, researcher and administrator of the Office of Dean of the Faculty of E-Learning Technologies and Humanities of Riga Technical University. She is a member of the Association of Journalists (Republic of Latvia) and of the European Latvian Association. She is an author of multiple publications and several textbooks. She has been a guest lecturer in Latvian at foreign language courses at Savaria University Centre of the University of West Hungary (Hungary), at Johannes Gutenberg
Achievements of Engineer,

Entrepreneur and

Teacher

Jānis Baumanis (1878-1945) 


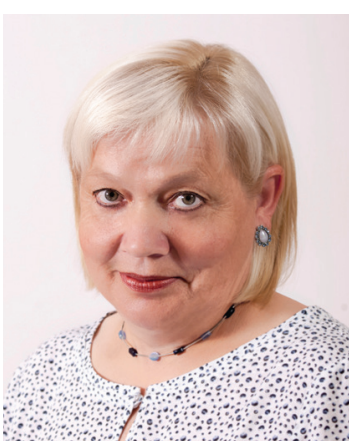

ALİDA ZIGMUNDE, Dr. paed., has been a Specialist with the Museum of Riga Technical University since 1989. From 2007 to 2015, she was a Senior Researcher. She is currently a Professor with the Institute for Humanities and Head of the Department for Historic Research and Scientific Publications of the RTU Research Centre for Engineering History. Her main academic interests include the history of pedagogy in Europe, the history of educational institutions and of private schools and the history of pedagogy of universities, of engineering sciences and universities.

Address: 1 Kronvalda bulvāris, Room 203, Riga, LV-1010, Latvia

Phone: +37129869642

E-mail: alida.zigmunde@rtu.lv

Lāsma Gaitniece, Alīda Zigmunde

\section{Inženiera, uzṇēmēja, skolotāja Jāṇa Baumaṇa (1878-1945) mūža veikums}

Raksts veltīts inženierim, pedagogam un vienam no Liepājas pilsētas pašvaldības vadītājiem Jānim Baumanim, kurš augstāko izglītību ieguva ne tikai Rīgas Politehniskajā institūtā (RPI), bet arī elektroenerǵijas augstskolā «Ecole supérieure d'electricité» Parīzē, Francijā. Jāṇa Baumaṇa biogrāfija liecina, ka viṇš bijis mērḳtiecīgs, nav baidījies jaunu izaicinājumu, kā arī vairākkārt sevi veiksmīgi pierādījis uzṇēmējdarbībā, dibinot un sekmīgi vadot uzṇēmumus. Minētās īpašības raksturo Jāni Baumani arī kā Liepājas pašvaldības vadītāju, taču vēlme uzṇemties iniciatīvu dažādu tolaik vēl pārdrošu ideju realizēšanā augstajam amatam bijusi traucējoša, tādēl viṇš pilsētas vadībā bija vien nepilnu gadu. Atkāpjoties no pašvaldības vadītāja amata, vinš̌ Liepāju pameta un devās uz Rīgu, kur strādāja firmā un pievērsās pedagogiiskajam darbam. Raksta mērksis - apkopot Jāna Baumaṇa dzīves gājumu un atklāt viṇa veikumu dažādās darbības jomās.

Atslēgas vārdi: Jānis Baumanis, Rīgas Politehniskais institūts, Liepājas pilsētas pašvaldība, uzñēmums «Rūpnieks».

Ласма Гайтниеце, Алида Зигмунде

\section{Жизненный вклад инженера, предпринимателя, педагога Яниса Бауманиса (1878-1945)}

Статья посвящена инженеру, педагогу и одному из руководителей самоуправления Лиепаи Янису Бауманису, который получил высшее образование не только в Рижском политехническом институте (РПИ), но и в высшей школе электричества «Ecole supérieure d'electricité» в Париже, Франция. Биография Яниса Бауманиса свидетельствует, что он был целеустремленным, не боялся новых вызовов и неоднократно доказывал, что он успешен в предпринимательской деятельности, создавал и 
успешно управлял компаниями. Эти качества также характеризуют Яниса Бауманиса как главу Лиепайского самоуправления, но желание проявить инициативу в реализации различных идей, которые считались безрассудно смелыми в то время, были помехой для его высокой должности, поэтому он руководил городом всего год. Оставив пост главы самоуправления, он покинул Лиепаю и уехал в Ригу, где работал на фирме и занялся педагогической работой. Целью статьи - подвести итоги жизни Яниса Бауманиса и раскрыть его достижения в различных сферах деятельности.

Ключевые слова: Янис Бауманис, Рижский политехнический институт, Лиепайская городская дума, фирма «Rūpnieks».
Achievements of Engineer,

Entrepreneur and Teacher

Jānis Baumanis (1878-1945) 